\title{
KEPEMIMPINAN FX.HADI RUDYATMO DALAM MEWUJUDKAN SOLO KOTA LAYAK ANAK
}

\section{Yunita Ratna Sari}

\begin{abstract}
Solo is one of the two Cities in Indonesia that received the highest award of District / City Worthy Children's implementation from President JokowiWidodo as the City of Eligible Children. The success of Solo to get the award of Decent Child's City can not be separated from the leadership FX.HadiRudyatmo as the Mayor of Solo. The objectives of this research are: (1) To know and explain the leadership of FX.HadiRudyatmo in realizing the Solo of Decent City, (2) To analyze and analyze the factors that make Solo Municipal Children's Favorite and (3) to know and analyze the actors who contribute greatly in Solo Kota Decent Children. The method used in this study is a qualitative descriptive approach that explains the results of research, assessment and other references reinforced by empirical data conducted through interviews and observation. The results showed that the leadership of FX.HadiRudyatmo in realizing the Decent City Solo is very democratic but the egosektoral among the Organization of Regional Devices in realizing the Solo Municipal Decent Children is still high and there are still problems that can not be resolved even though Solo gets the predicate Solo Kota Major Main is the number of children who exposed to HIV / AIDS is still high and the availability of child data information management system. Recommendations given to the Government are to build more intense communications and improve routine coordination among the Regional Device Organizations through scheduled meetings amongst the WTO, promoting socialization and education to all levels of society on HIV / AIDS as well as the creation of a web data base on child data.
\end{abstract}

Keywords: Leadership, Head of Region, District / City Eligible Children

\section{A. PENDAHULUAN}

Di era reformasi ini, tepatnya sejak tahun 2001, paradigma sentralisasi berubah menjadi desentralisasi dengan diberlakukannya UU No 22 Tahun 1999tentang Pemerintahan Daerah dan UU No 25 Tahun 1999 tentang Perimbangan Keuangan Pusat dan Daerah. Kedua Undang- Undang itu, daerahmemperoleh kewenangan dalam bentuk otonomi daerah sebagai konsekuensi dari desentralisasi untuk mengatur dan mengelola wilayahnya sendiri bersama- sama dengan rakyat yang melibatkan kearifan lokal. ${ }^{1}$

Pelaksanaan otonomi daerah sejak 1 Januari 2001, diharapkan dapat memberikan pelayanan kepada masyarakat secara efektif dan efisien. Namun, hingga sekarang ini kualitas pelayanan publik masih diwarnai oleh pelayanan yang sulit untuk diakses, prosedur yang berbelit-belit ketika harus mengurus suatu perijinan tertentu,

\footnotetext{
${ }^{1}$ Irwan Waris.2012. "Pergeseran Paradigma Sentralisasi ke Desentralisasi Dalam Mewujudkan Good Governance”. Jurnal Kebijakan Publik, Volume 3, Nomor 1, Maret 2012. https://www.download.portalgaruda.org diakses 22 April 2017, pukul 05.36 WIB. Halaman 39.
} 
biaya yang tidak jelas serta terjadinya praktek pungutan liar (pungli). ${ }^{2}$ Omdusman RI mendapati adanya praktik pungutan liar pada pelayanan pembuatan KTP elektronik yang tersebar di 12 Provinsi antara lain Provinsi Banten, Bengkulu, Jambi, Jawa Barat, Jawa Tengah, Jawa Timur, Kalimantan Barat, Kalimantan Selatan, Kalimantan Tengah, Nusa Tenggara Barat, Sulawesi Selatan, dan Sumatra Selatan. Jumlah pungutan liar dalam pelayanan KTP elektronik itu bervariasi, paling tinggi Rp 300 ribu per orang. ${ }^{3}$ Selain adanya pungli sebagai bukti buruknya kualitas pelayanan publik di daerah, juga ditandai dengan banyaknya laporan masyarakat terkait pelayanan publik terhadap Pemerintah Daerah.

Tabel 1.1 Laporan Masyarakat Berdasarkan Instansi Terlapor Periode 2013- 2015

\begin{tabular}{|l|c|c|c|}
\multirow{2}{*}{\multicolumn{1}{|c|}{ Instansi }} & \multicolumn{3}{c|}{ Jumlah } \\
\cline { 2 - 4 } & 2013 & 2014 & 2015 \\
\hline Pemerintah Daerah & 2.329 & 2.887 & 2.854 \\
\hline Kepolisian & 668 & 852 & 816 \\
\hline Instansi Kementrian & 520 & 637 & 661 \\
\hline Badan Pertanahan Nasional & 365 & 520 & 530 \\
\hline BUMN/ BUMD & 350 & 512 & 629 \\
\hline Lain- lain & 236 & 394 & 392 \\
\hline Lembaga Peradilan & 237 & 256 & 262 \\
\hline Lembaga Pendidikan Negeri & 60 & 54 & 146 \\
\hline Perbankan & 65 & 102 & 140 \\
\hline Lembaga Pemerintah Non Kementrian & 60 & 67 & 55 \\
\hline TNI & 29 & 36 & 39 \\
\hline DPR & 28 & 24 & 20 \\
\hline Kejaksaan & 127 & 119 & 117 \\
\hline Komisi Negara & 96 & 99 & 67 \\
\hline Perguruan Tinggi Negeri & - & 81 & 70 \\
\hline BPK & 3 & - & - \\
\hline Rumah Sakit Pemerintah & - & 37 & 71 \\
\hline Jumlah Total & 5.137 & 6.677 & 6.869 \\
\hline
\end{tabular}

Sumber : Ombudusman RI Tahun 2015

Berdasarkan tabel 1.1 dapat dilihat bahwa dari tahun 2013 sampai 2015, instansi terlapor yang menempati urutan pertama terbanyak yaitu Pemerintah Daerah dari 2.329 laporan di tahun 2013 mengalami peningkatan di tahun 2015 menjadi 2.854 laporan. Laporan keluhan masyarakat di Pemerintah Daerah berkaitan dengan konflik kepentingan sebanyak 71,9\%, permintaan uang barang dan jasa (pungli) sebanyak 69,9 $\%$ dan penundaan berlarut yang mencapai $25,9 \%{ }^{4}$

Permasalahan pelayanan publik di daerah yang kompleks menyebabkan dituntutnya cara- cara baru untuk menyelesaikan masalah publik melalui inovasi. Dengan adanya

\footnotetext{
2 Hasbullah Malau. 2009. "Menyoal Pelayanan Publik yang Berkualitas di Era Otonomi Daerah". DEMOKRASI Vol. VIII No. 1 Th. 2009. https://www.ejournal.unp.ac.iddiakses 22 April 2017, pukul 06.00 WIB Halaman 2.

${ }^{3}$ https://beritagar.id/artikel/berita/ada-pungli-dalam-pembuatan-e-ktp-di-12-provinsi diakses 22 April 2017, pukul 10.50 WIB

${ }^{4}$ http://www.pikiran-rakyat.com diakses 22 April 2017, pukul 10.59 WIB
} 
inovasi sektor publik diharapkan akan memberikan pelayanan publik yang bermutu tinggi, optimal dan prima kepada masyarakat yang akhirnya dapat meningkatkan kesejahteraan masyarakat. Salah satu inovasi sektor publik yang menarik untuk dibahas yaitu Kabupaten/ Kota Layak Anak (KLA) diinisiasi oleh Kementrian Pemberdayaan Perempuan dan Perlindungan Anak yang mengintegrasikan semua komitmen dan sumber daya Pemerintah, masyarakat dan dunia usaha yang terencana, menyeluruh serta berkelanjutan untuk menjamin terpenuhinya hak dan perlindungan anak. Hal yang melatarbelakangi munculnya KLA yaitu kepentingan anak belum menjadi pusat pembangunan di Kabupaten dan Kota.Selama ini, PemerintahKabupaten dan Kota lebih memusatkan pada bidang ekonomi, politik dan infrastruktur tanpa mempertimbangkan unsur kepentingan terbaik anak dalam pengambilan keputusan. Padahal jumlah anak sebesar 80,1 juta atau sepertiga jumlah penduduk Indonesia merupakan generasi penerus bangsa yang akan meneruskan cita- cita bangsa. Dengan adanya KLA ini diharapkan Kabupaten/Kota mampu memenuhi hak- hak dasar anak yang mencakup hak hidup, hak tumbuh dan berkembang, hak perlindungan, dan hak partisipasi serta dapat melindungi anak dari berbagai bentuk diskriminasi, eksploitasi dan kekerasan.

Dari 124 Kabupaten/ Kota di Indonesia, hanya ada 2 Kota yang memperoleh penghargaan tertinggi KLA, salah satunya Kota Solo atau lebih dikenal dengan Kota Surakarta. Hal itu dibuktikan dengan Solo mendapat penghargaan dari Presiden Joko Widodo sebagai Kota Layak Anak Kategori Utama pada tahun 2017. Seperti yang diketahui, dalam pelaksanaan KLA terdapat lima tingkatan penghargaan yaitu Pratama, Muda, Madya, Nindya, Utama dan Kota Layak Anak (KLA).

Keberhasilan Solo memperoleh penghargaan KLA tidak dapat dilepaskan dari FX. Hadi Rudyatmo sebagai Walikota Solo. Disebabkan berhasil tidaknya sebuah organisasi ditentukan oleh Pemimpinnya karena Pemimpin yang membuat keputusan, memotivasi bawahan untuk melaksanakan keputusan yang dibuat dan mengawasi pelaksanaan keputusan untuk mencapai tujuan bersama dalam organisasi.

Mengacu pada latar belakang permasalahan diatas, peneliti tertarik untuk melakukan penelitian mengenai "Kepemimpinan FX.Hadi Rudyatmo dalam Mewujudkan Solo Kota Layak Anak. ”Rumusan masalah penelitian ini yaitu :

1. Bagaimana kepemimpinan FX.Hadi Rudyatmo dalam mewujudkan Solo Kota Layak Anak?

2. Faktor apa yang menjadikan Solo Kota Layak Anak ?

3. Siapa saja aktor yang berkonstribusi besar dalam Solo Kota Layak Anak ?

\section{METODE PENELITIAN}

Penelitian ini menggunakan metode penelitian kualitatif dengan tipe deskriptif untuk mendeskripsikan dan menggali secara mendalam terkait Kepemimpinan FX.Hadi Rudyatmo dalam mewujudkan Solo Kota Layak Anak. Informan dalam penelitian ini meliputi Walikota Solo (FX.Hadi Rudyatmo), Badan Perencanaan dan Pembangunan Kota Surakarta, Dinas Kesehatan Kota Surakarta, Dinas Sosial Kota Surakarta, LSM Seroja, Akademisi, Dunia Usaha. Data-data yang diperoleh penulis adalah Data Primer(diperoleh melalui wawancara)dan data sekunder(diperoleh melalui analisis dokumen seperti modul profil anak). Data yang telah diperoleh diuji menggunakan teknik triangulasi dengan membandingkan data yang diperoleh dari satu sumber dengan data yang di dapat dari sumber lain.

\section{B. PEMBAHASAN}

\section{Kepemimpinan FX.Hadi Rudyatmo dalam Mewujudkan Solo Kota Layak Anak}


Dalam mewujudkan keberhasilan pelaksanaan inovasi sektor publik tidak dapat dipisahkan dari kepemimpinan. Kepemimpinanmerupakan seperangkat tindakan dan perilaku tertentu yang mampu mengerakkan perubahan dalam organisasi. ${ }^{5}$ Berkaitan dengan Kepemimpinan FX. Hadi Rudyatmo dalam mewujudkan Solo Kota Layak Anak sangat demokratis.Hal itu dapat dilihat dari sikap beliau dalam melakukan beberapa hal antara lainDalam memberikan tugas, Bapak Rudy mengacu pada visi misi 3 WMP (Waras, Wasis, Wareg, Mapan, Papan) (Wawancara dengan Kepala Bidang Rehabilitasi dan Jaminan Sosial, Dinas Sosial Kota Surakarta, 9 Juni 2017). Bapak Rudy dalam memberikan tugas kepada Organisasi Perangkat Daerah jelas dan rinci. Adanya kejelasan tugas dan komunikasi terbuka serta dua arah yang telah dilakukan Bapak Rudy dengan Organisasi Perangkat Daerah menyebabkan Organisasi Perangkat Daerah mau menerima tugas tanpa paksaan dan mengetahui secara jelas bagian- bagian tugas yang akan dilaksanakan sesuai tugas masing- masing Organisasi Perangkat Daerah.

Dalam proses pengambilan keputusan selalu melibatkan bawahan. Jelas dilibatkan, bentuknya layanan kesehatan khususnya di tumbuh kembang melalui Puskesmas dan Rumah Sakit. (Wawancara dengan Kepala Seksi Kesehatan dan Gizi, Dinas Kesehatan Kota Surakarta, 14 Juni 2017). Bapak Rudy selalu melibatkan partisipasi aktif Organisasi Perangkat Daerah sesuai tugasnya masing- masing. Tujuan melibatkan Organisasi Perangkat Daerah dalam proses pengambilan keputusan yaitu agar Organisasi Perangkat Daerah mempunyai rasa tanggungjawab yang besar untuk melaksanakan keputusan tersebut mengingat keputusan yang diambil merupakan keputusan bersama.

\section{Faktor yang menjadikan Solo Kota Layak Anak}

Terdapat 2 faktor utama yang menjadikan Solo Kota Layak Anak yaitu kelembagaan dan partisipasi. Kelembagaan dalam mewujudkan Solo Kota layak Anak sudah baik didukung oleh adanya peraturan, sumber daya manusia yang memadai dan struktur birokrasi yang baik.

Dalam mewujudkan Solo Kota Layak Anak terdapat aturan formal mulai dari Perda, Perwali, Surat Edaran mengenai Kota Layak Anak. (Wawancara dengan Kepala Bidang Perlindungan Anak, Dinas P3AKB Kota Surakarta, 5 Juni 2017).Beberapa peraturan utama yang berkaitan dengan anak diantaranya Peraturan Daerah No 10 Tahun 2002 tentang Penyelenggaraan Pendaftaran dan Akta Catatan Sipil Kota Surakarta,Peraturan Daerah No 4 Tahun 2012 tentang Perlindungan Anak Kota Surakarta,Peraturan Walikota No 6 Tahun 2008 tentang Petunjuk Pelaksanaan Pengelolaan Taman Cerdas Kota Surakarta, Peraturan Walikota No 13 Tahun 2010 tentang Kawasan Tanpa Rokok dan Kawasan Terbatas Merokok Kota Surakarta, Surat Keputusan Walikota Surakarta No 130.05/68F/1/2011 tentang Pembentukan Gugus Tugas Pengembangan KLA dan Surat Edaran Sekretaris Daerah Kota Surakarta No 440/4.416 tentang Pelaksanaan Rencana Aksi Kota Layak Anak dan Puskesmas Ramah Anak.

Pelaksanaan KLA di Solo sampai memperoleh predikat Solo Kota Layak Anak Utama dilaksanakan oleh pelaksana yang sebagian besar Sarjana dan terdapat lulusan Sarjana Psikologi. Sampai saat ini, pelaksana KLA mampu memberikan solusi melalui koordinasi.(Wawancara dengan Kepala Bidang Perlindungan Anak, Dinas P3AKB Kota Surakarta, 5 Juni 2017). Dari segi sumber daya manusia dalam mewujudkan Solo Kota

\footnotetext{
${ }^{5}$ Alfan Alfian.2016. “Mengapa Politik Menarik, Memperbincangkan Urgensi Kepemimpinan Politik”.Bekasi : PT.Penjuru Ilmu Sejati. Halaman 117-118.
} 
Layak Anak cukup memadai karena mayoritas kualifikasi pendidikan pelaksana KLA lulusan Sarjana dan terdapat lulusan Sarjana Psikologi yang jelas mendukung dan sinkron dalam pelaksanaan KLA mengingat kebijakan Kabupaten/Kota Layak Anak sasarannya anak- anak.Berkaitan dengan struktur birokrasi dalam mewujudkan Solo Kota Layak Anak beluma ada, baru dibuat, baru proses dengan pihak ketiga.(Wawancara dengan Kepala Bidang Perlindungan Anak, Dinas P3AKB Kota Surakarta, 5 Juni 2017). Pelaksanaan KLA di Solo sampai memperoleh predikat Solo Kota Layak Anak belum ada struktur birokrasi yang menjadi acuan bekerjanya pelaksana. Masing- masing OPD (Organisasi Perangkat Daerah) dalam mewujudkan Solo Kota Layak Anak mengacu pada SK Walikota Surakarta No 130.05/68F/1/2011 tentang Pembentukan Gugus Tugas Pengembangan KLA. Sehingga masing- masing OPD menjalankan KLA sesuai dengan tugas dan fungsi masing- masing.

Dalam mewujudkan Solo Kota Layak, semua pihak dilibatkan. Bentuk keterlibatannya, dalam hak sipil anak melalui Akte Kelahiran, Kartu Keluarga (KK), KIA (Kartu Insentif Anak) (Wawancara dengan Kepala Bidang Pengelolaan Informasi dan Kependudukan, Dinas Capil Kota Surakarta, 19 Juni 2017). Wujud keterlibatan lainnya yaitu penyusunan Perda Kota Surakarta tentang Perlindungan Anakdiawali dengan menyusun dan menganalisis situasi ibu dan anak, istilahnya ASIA (Wawancara dengan Kepala Prodi Magister Sosiologi UNS, 19 Juni 2017). Selain itu, keterlibatan melalui regulasi dengan membuat Perda tentang Kota Layak Anak. Perda yang melindungi hakhak anak misal dari sisi pendidikan dan kesehatan anak. (Wawancara dengan Anggota Komisi IV, DPRD Kota Surakarta, 12 Juni 2017). Kemudian bentuk keterlibatan lainnya dapat masuk dalam Tim Gugus Tugas KLA terutama di bidang perlindungan anak. (Wawancara dengan Ketuan LSM Seroja Surakarta, 9 Juni 2017). Selain itu juga dalam Dalam pemberian diskon kacamata bagi anak- anak yang memiliki Kartu Insentif Anak (Wawancara dengan Pegawai Toko Optik Pranoto Surakarta, 19 Juni 2017).

Dilihat dari tingkat partisipasinya, dalam mewujudkan Solo Kota Layak Anak semua dilibatkan tidak hanya dari OPD saja tetapi juga dari Akademisi, DPRD, LSM dan Dunia Usaha. Keterlibatan semua pihak sesuai dengan tupoksi masing- masing.Bentuk keterlibatan OPD dalam KLA terutama pelayanan dasar anak berupa program- program pro anak. Salah satunya Dinas pendidikan memiliki program GWJB (Gerakan Wajib Jam Belajar), anak- anak dihimbau untuk belajar dari pukul 18.30 WIB-20.30 WIB. Untuk mewujudkan keberhasilan pelaksanaan GWJB, dibentuklah Satgas GWJB tingkat RW dengan diberi tanda Sirene sebagai peringatan belajar pada jam belajar tersebut dan juga ada diperingatkan lewat Mesjid. Kemudian menciptakan Sekolah Ramah Anak.

Jumlah Sekolah Ramah Anak (SRA) Kota Surakarta Tahun 2015

\begin{tabular}{|c|c|c|c|c|c|c|c|}
\hline \multicolumn{3}{|c|}{ Jumlah Sekolah } & \multicolumn{4}{c|}{ Jumlah SRA } \\
\hline PAUD & SD/ & SMP/ & SMA/ & PAUD & SD & SMP & SMA/ \\
& MI/ & MTs/ & MA/ & & /MI/ & /MTs/ & MA \\
& SDLB & SMPLB & SMALB & & SDLB & SMPLB & SMALB \\
\hline 689 & 289 & 87 & 90 & 689 & 289 & 87 & 90 \\
\hline
\end{tabular}

Sumber : Dinas Dikpora Kota Surakarta Tahun 2015

\section{Aktor yang berkonstribusi besar dalam Solo Kota Layak Anak}

Dalam mewujudkan Solo Kota Layak Anak melibatkan berbagai aktor.Pihakpihaknya banyak mencakup Pemerintah Daerah kapasitas sebagai fasilitator digerakkan oleh Swasta, Perguruan Tinggi, masyarakat, ada Kepolisian, Bapas, Kementrian Agama, Rutan, ada LSM, ada organisasi kemasyarakatan. (Wawancara dengan Kepala Bidang Sosbud Pemerintahan Bappeda Kota Surakarta, 5 Juni 2017). Terdapat 3 aktor yang berkonstribusi besar dalam mewujudkan Solo Kota Layak Anak antara lain Pemerintah 
Kota Surakarta yang mencakup OPD KLA, Akademisi dan Dunia Usaha. Peran masingmasing aktor yaitu Pemerintah Kota Surakarta yang mencakup OPD KLA berperan sebagai melaksanakan pengembangan KLA, akademisi sebagai Tim Ahli dalam pelaksanaan KLA serta dunia usaha berperan pendukung pelaksanaan KLA berupa anggaran.

\section{ANALISIS}

Kepemimpinan Bapak Rudy dalam mewujudkan Solo Kota Layak Anak sangat demokratis dilihat dari sikap beliau yang selalu melibatkan OPD dalam proses pengambilan keputusan, membagi tugas dan mendelegasikan tugas kepada OPD melalui koordinasi rutin berupa rapat dan dalam menanggapi kritik serta saran dari masyarakat responsif dan segera ditindaklanjuti. Faktor yang menjadikan Solo Kota Layak Anak ada 2 yaitu kelembagaan dalam mewujudkan Solo Kota Layak Anak baik dilihat dari aturannya terdiri dari Perda, Perwali, Surat Keputusan Walikota dan Surat Edaran Sekda dan Kepala SKPD. Dilihat dari substansi aturan mengacu pada pemenuhan hak anak, dari segi SDM pelaksana KLA juga memadai karena mayoritas kualifikasi pendidikan lulusan Sarjana dan mampu memberikan solusi terkait masalah yang muncul dalam pelaksanaan KLA di Solo. Dari segi struktur birokrasi mengacu pada SK Walikota Surakarta No 130.05/68F/1/2011 tentang Pembentukan Gugus Tugas Pengembangan KLA yang sesuai fungsi masing- masing.

Permasalahan yang belum dapat terselesaikan meskipun Solo memperoleh predikat Solo Kota Layak Anak Utama antara lain jumlah anak yang terkena HIV/AIDS masih tinggi, masih adanya kasus kekerasan anak, egosektoral yang masih tinggi antar OPD KLA dan belum tersedianya sistem informasi terkait dengan data anak.

Jumlah Anak dan Dewasa yang Terinfeksi HIV/AIDS Kota Surakarta.

\begin{tabular}{|c|c|}
\hline Tahun & $\begin{array}{c}\text { Jumlah Anak usia (0-19 tahun ) } \\
\text { yang terinfeksi HIV/AIDS }\end{array}$ \\
\hline 2005 sampai 2016 & AIDS $: 67$ anak \\
HIV $: 48$ anak
\end{tabular}

Sumber : Komisi Penanggulangan AIDS (KPA) Kota Surakarta Tahun 2016

Jumlah Kekerasan Anak Kota Surakarta Tahun 2016- Juni 2017

\begin{tabular}{|c|c|}
\hline Jenis Kekerasan & Jumlah Anak Korban Kekerasan \\
\hline Kekerasan Sex & 12 \\
\hline Kekerasan Fisik & 0 \\
\hline ABH & 6 \\
\hline Antar dalam keluarga & 2 \\
\hline
\end{tabular}

Sumber : PLKSAI Tahun 2017

Menurut data KPA, jumlah anak terkena HIV/AIDS usia 0-19 dari tahun 2005 2016 sebesar 115 anak dengan rincian anak terkena AIDS sebanyak 67 anak dan anak terkena HIV sebanyak 48 anak.Jumlah kasus kekerasan anak di Kota Solo menurut data PLKSAI dari tahun 2016 sampai Juni 2017 berjumlah 20 anak terdiri dari kekerasan sex, 12 anak, ABH sebanyak 6 anak dan kekerasan antar keluarga sebanyak 2 orang. Bukti egosektoral OPD KLA masih tinggi yaitu masih adanya OPD yang lempar tanggungjawab terkait tugas yang diberikan seperti dalam mengatasi kekerasan anak, banyak OPD yang 
yang berpandangan bahwa itu wewenangnya Dinas P3APM Kota Surakarta sebagai leading sector, padahal sebenarnya kasus kekerasan anak itu tanggungjawab bersama karena terkait dengan masalah anak yang kompleks.

\section{PENUTUP}

Dari hasil penelitian dapat ditarik kesimpulan sebagai berikut :

1. Kepemimpinan FX.Hadi Rudyatmo dalam mewujudkan Solo Kota Layak Anak demokratis dilihat dari sikapnya yang selalu melibatkan bawahannya dalam proses pengambilan keputusan dan mengatasi hambatan menggunakan musyawawah mufakat.

2. Faktor yang menjadikan Solo Kota Layak Anak terdiri dari kelembagaan dan partisipasi. Kelembagaan dalam mewujudkan Solo Kota Layak Anak baik dilihat dari adanya aturan yang jelas berupa Peraturan Daerah, Peraturan Walikota, Surat Edaran dari Sekda maupun Kepala SKPD dan adanya partisipasi aktif dari berbagai pihak baik pemerintah, non pemerintah, swasta dan akademisi.

3. Aktor yang berkonstribusi dalam Solo Kota Layak Anak dikelompok menjadi 3 yaitu Pemerintah Kota Surakarta, Akademisi dan Swasta.

Rekomendasi yang bisa diberikan terkait Kepemimpinan FX.Hadi Rudyatmo dalam Mewujudkan Solo Kota Layak Anak sebagai berikut :

1. Komunikasi dan koordinasi antar OPD KLA harus ditingkatkan untuk mengurangi egosektoral antar OPD yang masih cukup tinggi mengingat persoalan anak sangat kompleks dan melibatkan berbagai pihak. Dengan adanya komunikasi dan koordinasi yang baik dengan berbagai OPD KLA diharapkan OPD KLA tidak saling lempar tanggungjawab dan menggantungkan kepada OPD tertentu seperti Dinas P3A PM Kota Surakarta.

2. Sosialisasi dan edukasi kepada semua lapisan masyarakat (orang tua, kelompok arisan, kelompok PKK, Karang Taruna, LKMD) harus ditingkatkan terutama terkait dengan hakhak anak termasuk juga masalah- masalah yang belum dapat terselesaikan seperti kekerasan anak dan anak terkena HIV/AIDS serta lebih mengaktifkan organisasi masyarakat sehingga kasus kekerasan anak dan anak terkena HIV/AID dapat teratasi dan masyarakat lebih mengetahui informasi terkait HIV/AIDS dari cara pencegahan dan penanggulangannya.

3. Harus ada pembuatan Web yang mengintegrasikan berbagai OPD terutama terkait dengan data anak sehingga data anak tidak tumpang tindih dengan berbagai OPD KLA lain.

\section{D.DAFTAR REFERENSI}

Suwarno, Yogi. 2010. Inovasi Sektor Publik.. Jakarta : STIA LAN Press

David Alburry and Geoff Mulgan.2003. Innovation in The Public Sector. Landon : The Mall.

Noor, Irwan. 2013.Desain Inovasi Pemerintahan Daerah. Malang: UB Press

Sulistiyani, Ambar Teguh. 2008. Kepemimpinan Profesional, Pendekatan Leadership Games. Yogyakarta : GAVA MEDIA.

Kaloh, J.2009. Kepemimpinan Kepala Daerah, Pola Kegiatan, Kekuasaan dan Perilaku Kepala Daerah Dalam Pelaksanaan Otonomi Daerah. Jakarta : Sinar Grafik

Pasolong, Harbani. 2015. Kepemimpinan Birokrasi. Bandung : CV. ALFABETA.

Yulk, Gary. 2015.Kepemimpinan Dalam Organisasi. Jakarta : INDEKS

Etzkowitz, Henry. 2008. The Triple Helix, University-Industry-Government Innovation in Action. New York : Routledge.

W. Cresswell, John.2015. Penelitian Kualitatif dan Desain Riset, Memilih Diantara Lima Pendekatan. Yogyakarta : Pustaka Pelajar.

Jurnal 
Moh Ilham A Hamudy. 2015. Upaya Mewujudkan Kota Layak Anak Kota Surakarta dan Makassar. Jurnal Bina Praja Volume 7 No 2 Edisi Juni 2015.

Irwan Waris.2012. Pergeseran Paradigma Sentralisasi ke Desentralisasi Dalam Mewujudkan Good Governance. Jurnal Kebijakan Publik, Volume 3, Nomor 1, Maret 2012. WEBSITE

http://mediaindonesia.com/editorial/read/299/pelayanan-buruk-pemerintah-daerah/201412-19 diakses 22 April 2017, pukul 14.03WIB

http://www.kompasiana.com/amirsyahoke/masih-banyak-anggaran-belanja-negara-yangbisa-dihemat 57be83ddf3967335434b93a2 diakses 22 April 2017, pukul 14.21WIB 